\title{
WILLIAM COBBETT: PHILADELPHIA BOOKSELLER AND PUBLISHER
}

\author{
BY C. REXFORD DAVIS
}

IN his article on Cobbett in the December 195 I number of the Journal, Professor Davis promised to discuss in a forthcoming number a letter written by Cobbett on January 5, 1829. Since then, however, the Library has acquired another Cobbett letter, of such importance as to deserve prior treatment. The 1829 letter is therefore postponed at this time.

WHE FOLLOWING LETTER-written by William Cob-
bett to Robert Goodloe Harper, Member of the House of
Representatives for South Carolina from February 9, I 795,
to March 4, I 8 OI-contributes in two ways to his biography: It
casts light on his relationship with an influential leader of the Fed-
eralists in the House, and it shows something of the extent of his
activities as a bookseller and publisher. The bill referred to in the
letter, together with explanations of its items, is transcribed at the
end of this article.

New York, 20. Jan. I 800.

Sir,

Enclosed I take the liberty to send you my bill; the date from Nov. I 797 to August I 799; the amount Dolls. I $26=071 / 2$, which I request you to pay to the bearer, or to send it me on by post, first deducting whatever you may deem a competent fee for the part you took in the late cause of Rush against me. If you should have any objections to the bill (for which, however, I can see no good reason), I beg you will be so good as to state them as soon as possible, the decision that Rush has obtained against me rendering it absolutely necessary for me to use all the dispatch I am master of in collecting my debts of every discription.

$$
\begin{aligned}
& \text { I am, } \\
& \text { Sir, } \\
& \text { Your humble Serv }{ }^{\mathrm{t}} . \\
& \quad \mathrm{W}^{\mathrm{m}} \text {. Cobbett. }
\end{aligned}
$$

Rob $^{\mathrm{t}}$. Goodloe Harper, Esqr.

Mem. Cong. Philadelphia. $\}$ 
The bill accompanying this letter lists charges from November 6, I 797, to August 28, I 799. These charges covered purchases by Harper of writing paper, pamphlets published by Cobbett, books and pamphlets published by other American booksellers, and books and pamphlets imported by Cobbett. The bill also lists an item the charge for which began many months before November 6, I 797: the subscription costs of Porcupine's Gazette, Cobbett's daily newspaper, for the entire term of its publication as a daily (March 4, I 797, to August 28, I 799). ${ }^{1}$

On the reverse side of this bill Harper entered the amounts which he considered due him from Cobbett. It is this reverse side which is reproduced opposite page 23. Harper's entries here concern "the case of Rush against me" of Cobbett's letter. Let us begin by reviewing this case, together with its political background.

During the years I794 to I797-it was in October of the latter year that Dr. Rush entered his suit against Cobbett-the latter had been chiefly active as a political writer against the Jacobins and the Democrats. A master of abuse and satire as political weapons, he had become highly regarded in America by the partisans of England, and even more bitterly hated by the Democrats, who were partisans of France.

The enmity of one Democrat in particular was greatly intensified during the year I797. In this year Cobbett was prosecuted for libels on the King of Spain and on the Spanish Minister. The trial took place in the State Court of Pennsylvania before Chief Justice Thomas M'Kean-Democratic politician prominent in state and city, and father-in-law of the Spanish Minister. Although M'Kean charged the jury to find against Cobbett, the jury by a majority of one threw out the charges. This case Cobbett vigorously reviewed in The Democratic Judge, ${ }^{2}$ issuing the pamphlet to discredit M'Kean and bitterly attacking M'Kean's principles and his public and private life. Justified though Cobbett may well have been in these attacks on M'Kean, the publication was ill-considered: it stored up bitter hatred against the day of retribution.

${ }^{1}$ Nine further issues of the Gazette appeared. Nos. 771-776 were issued fortnightly in folio from Sept. 6 to Oct. I I, 1799. Nos. $777-778$ ( I 2 mo.) appeared with successive pagination ( $1-24 \& 25-48)$ on Oct. 19 and 26,1799 . No. 779, the final number, was issued at New York City January 1 3, 1800 .

${ }^{2}$ See notes to Harper's bill, p. 24. Reissued in Vol. vir of Porcupine's Works (London, I 80 I) under title of The Republican Judge. 
Later in 1797 Cobbett made strong attacks upon Dr. Benjamin Rush-signer of the Declaration of Independence, Physician-General in charge of military hospitals for the army from April, I 777, to January 30, I778, well-known popular physician and writer on medicine. The latter, during the yellow-fever epidemic of I 793, had devised his own treatment for the disease: he bled his patients regularly and copiously and at the same time treated them with "mercurial purges" known as "Rush's powders." The treatment gained wide public favor, though on the whole it was disapproved by contemporary medical opinion.

The physicians who had whatever real success was gained in treating the disease were the French physicians practicing in Philadelphia, led by Dr. Jean Devèze, who had had much experience in treating the disease during his years in charge of a hospital in Santo Domingo. Devèze carefully studied Rush's methods, even conducting autopsies of the dead who had received Rush's treatment and of those who had not. He called Rush's powders "very fatal medicines" and his "bloodletting mortal." Moreover, he said of Rush by clear implication that he was "a scourge more fatal to the human kind than the plague itself would be." ${ }^{\text {a }}$ In spite of this opinion Dr. Rush was in 1793 the most popular physician in the city.

When in 1797 another epidemic of yellow fever occurred, it was natural that the press of Philadelphia should recommend Dr. Rush. But the publishers of two most influential papers dissented. John Ward Fenno, publisher of the United States Gazette, and William Cobbett, publisher of Porcupine's Gazette, "together . . . launched an attack on the treatment in general and its chief exponents in particular, concentrating especially on Dr. Rush. . .." The attack, begun by Fenno, "was soon afterwards followed by torrents of abuse in a paper conducted by one Cobbett. . ." In both papers these attacks-begun August 24, I797-continued until after October 2, I 797. On the latter date Rush brought libel suits against both Cobbett and Fenno. Yet the most important attack on Rush was to come later with the publication of an anonymous article, actually written by the Philadelphian physician William Currie and entitled "Information concerning Dr. Rush's Conduct and Transactions during

${ }^{3}$ Powell, J. H., Bring Out Your Dead, Philadelphia, 1949, p. 162.

4 Mary E. Clark, Peter Porcupine in America, Philadelphia, 1939, p. 146.

${ }^{5}$ The Autobiography of Benjamin Rush, ed. George W. Corner, Princeton, 1948, p. 99.

${ }^{6}$ Ibid. 
the Prevalence of the Malignant Fever in I 793. Communicated by one of the Members of the College of Physicians." This appeared in Fenno's paper on October 6, I797, and was reprinted by Cobbett in Porcupine's Gazette on the following day. According to Dr. Rush this article was of all the attacks the "most malignant."

In Dr. Rush, Cobbett had a welcome target. He had himself a particular horror of the nearly universal practice of blood-letting. Besides, to him any Democrat was fair prey, and Dr. Rush was prominent among Philadelphia Democrats. Here was an opportunity not to be missed. Cobbett nicknamed his victim "Doctor Sangrado," a reference to the bleeding physician in Gil Blas. He went at him hammer and tongs, not principally with argument based on such medical opinion as that of Devèze and Currie, but with the weapons he knew best, abuse and satire.

Rush's suit against Fenno was dropped in December. But that against Cobbett was continued and from time to time postponed. Cobbett attempted to get the suit transferred to Federal Court, alleging that as an alien he would receive fair trial only there. However, Chief Justice M'Kean ruled against him in March, I798. But the case was still not brought to trial. In this year, against Cobbett's strong journalistic efforts, M'Kean was elected governor. He consolidated his position by appointing his own judges, thereupon gradually proceeding to make Philadelphia and Pennsylvania too hot for Cobbett, who consequently, on August 28, I 799, suspended the daily publication of Porcupine's Gazette, went about removing his bookselling and publishing business to New York, and shipped most of his household effects to that city, remaining in Philadelphia only for the trial.

Somehow, however, Cobbett was brought to believe that the trial would not be held before the next sessions, so that on December 9, I 799, he departed for New York City to get his business under way there. But hardly had he left Philadelphia when the trial was hurried on. It was actually held without the defendant, beginning on December I3, for word of the trial failed to reach him in time. In his absence his lawyers were unable to make an effective defense. They attempted to show that there was no malicious intent on his part. However, the prosecution asserted that no alien could have taken Cobbett's stand on the question without intending malice. His

${ }^{7}$ Ibid. 
defense was unable to counter this argument effectively, though Cobbett himself undoubtedly could have done so. ${ }^{8}$

The trial was presided over by Chief Justice Shippen, an appointee of M'Kean. He ended his charge to the jury by urging it to award exemplary damages. "The jury, after taking but two hours to ponder, brought in a verdict for the plaintiff of five thousand dollars!" This sum, according to Cobbett, was greater than the sum total of all previous awards for libel in American Courts. Moreover, he was given no opportunity to pay. Officers of the State attached all of his property in Philadelphia without delay and sold it at once for what it would bring. For example, Cobbett's whole printing of Porcupine's Works, then in sheets awaiting issue, was sold as waste paper.

Cobbett lost greatly by this destructive act, for this edition was a project of some ten months' standing, soon to be brought to fruitful profit. ${ }^{10}$ His total losses due to the suit-including award, costs, and damages-must have been nearly $\$$ IO,OOO. Perhaps the best comment on the whole affair is that of the Dictionary of American Biography in its article on Cobbett: "It is clear that Rush was libeled and deserved to be libeled, but the trial was unfair."

In the "case of Rush against me" the place of Robert Goodloe Harper was a prominent one, for he was attorney in charge of Cobbett's defense. His choice was a natural one for Cobbett to make. The two men were both strongly pro-British in sympathy and they had been allied in this cause since I 797. Indeed, among "the members of the Federal party Cobbett's closest relations were with . . . Harper." 11 The latter had opened an account with Cobbett in 1796, and it was not long before he was receiving literary advice from his bookseller. Cobbett said that he gave Harper help in polishing up his speeches and, so far as Harper's Dispute is concerned (see notes at the end), "furnished the materials, gave the hints, drew the plan, and if my name had been put to work, I should not have been so much of a plagiarist as he was." ${ }^{12}$ This work in its first edition was published by Thomas Bradford, but in May, I 798, Cobbett published the third American edition.

${ }^{8}$ Clark, pp. 1 53-155. ${ }^{9}$ Ibid., p. 156.

${ }^{10}$ Cobbett had issued in February, 1799, this prospectus: "By William Cobbett, of the City of Philadelphia. Proposals for publishing by subscription; a new, entire, and neat edition of Porcupine's Works. Subscribers names. [Philadelphia: Printed by William Cobbett, Feb. 5, 1799.]"

${ }^{11}$ Clark, p. I 33.

12 Porcupine's Works quoted by Clark, p. 133. 
Earlier in the year the business association of the two men had begun to flourish. Cobbett was the authorized publisher of Harper's speech in the House of Representatives on March 2, I 798, 50 copies of this speech being charged to Harper on March 30 as " 50 Do. March." About this time he also published a speech which Harper had made in the House on May 29, I 797. Cobbett's bill itemizes under various dates a total of 65 copies of this speech. Soon after the publication of these two speeches arrangements were made for the publication by Cobbett of the third American edition of Harper's "Observations on the Dispute Between the United States and France." This edition was more than a re-setting of previous editions, for it contained a lengthy appendix prepared by Harper, and first printed in this edition, entitled: "Abstract of the Instructions Extraordinary to the Envoys of the United States, for Settling their Differences with the French Republic." It is interesting to note that although the third edition of the "Dispute" was published in May, Cobbett delivered to Harper 26 copies of the Instructions to Envoys on April 14. These are what would today be called pre-prints. No copies of this separate item have, apparently, survived.

Before the summer of 1798 had passed Cobbett was to publish yet another pamphlet for the Congressman: "A Short Account of the Principal Proceedings of Congress in the late session, and a Sketch of the State of Affairs between the United States and France in July, r 798, in a Letter from Robert Goodloe Harper, of South Carolina, to one of his constituents." Cobbett delivered printed copies of this letter to Harper on August I. This speed of publication-the letter is dated July 23, I 798-is somewhat greater than can be expected from latter-day publishers.

After this date Cobbett published no more for Harper-but neither did any other publisher do so during the years 1798 and I 799. Harper may well have been out of town during the epidemic season of 1798 , but he was back in town and patronizing Cobbett as bookseller in December, and again at intervals until May, 1799. Why the sales stopped at this time there is no telling.

However, Harper remained Cobbett's lawyer. He was in charge of the efforts in December, I797, and March, I798, to get the case of Rush transferred to federal court. The first of the two charges which he paid for Cobbett-and which appear as deductions from his bill (see opposite p. 23) - was made by the lawyers employed to 
secure the transfer. Their efforts came to nothing. The second of these two charges was made by the lawyers for their services in the trial itself. In the trial Harper also spoke in Cobbett's defense, seeking to prove that in Cobbett's attacks on Rush there had been a lack of malicious intent. The verdict testifies to his failure.

Cobbett felt betrayed by his friend. But it was characteristic of the man to expect from his friends and associates results that he alone could have achieved. He judged others by his own tremendous energies and by his own genius. The most self-confident of men, he was at the same time one who felt that what he could do others could do also. So far as we know, Cobbett did not accuse Harper directly of treachery, though he did level accusations ágainst his defense attorneys. But we can note here the coldness of the letter requesting payment. Its language in no way suggests that the two men had been warm friends and close associates.

How did Harper receive this coldness? The letter asks him to deduct "whatever you may deem a competent fee." Yet he deducts no fee whatever; he deducts only the sums paid in Cobbett's behalf. It is not recorded that he received any thanks for this generosity. Yet the generosity itself is not surprising, even in the face of coldness. Throughout Cobbett's life we find a long list of friends who served him well with no thought of reward. He had most certainly a real genius for friendship-as indeed he had for enmity also. He had made Harper his friend, so much so that in the face of coldness and enmity he still behaved as a friend.

From the charges in Cobbett's bill we learn not only of his activities as publisher for Harper but also of other activities as bookseller and publisher. In addition to the works which he published for Harper as discussed above, he sold Harper items which can be classified as follows:

His own writings, published by himself

Republications of foreign works in association with other publishers

Republications of foreign works alone

American works by other publishers at Philadelphia

Boston

Imported works, probably obtained from the bookseller John Wright of London

Democratic Judge

Proofs of a Conspiracy

Cannibal's Progress

Report on Finance

Revolution in Russia

It may be noted that the works imported by Cobbett included, in 


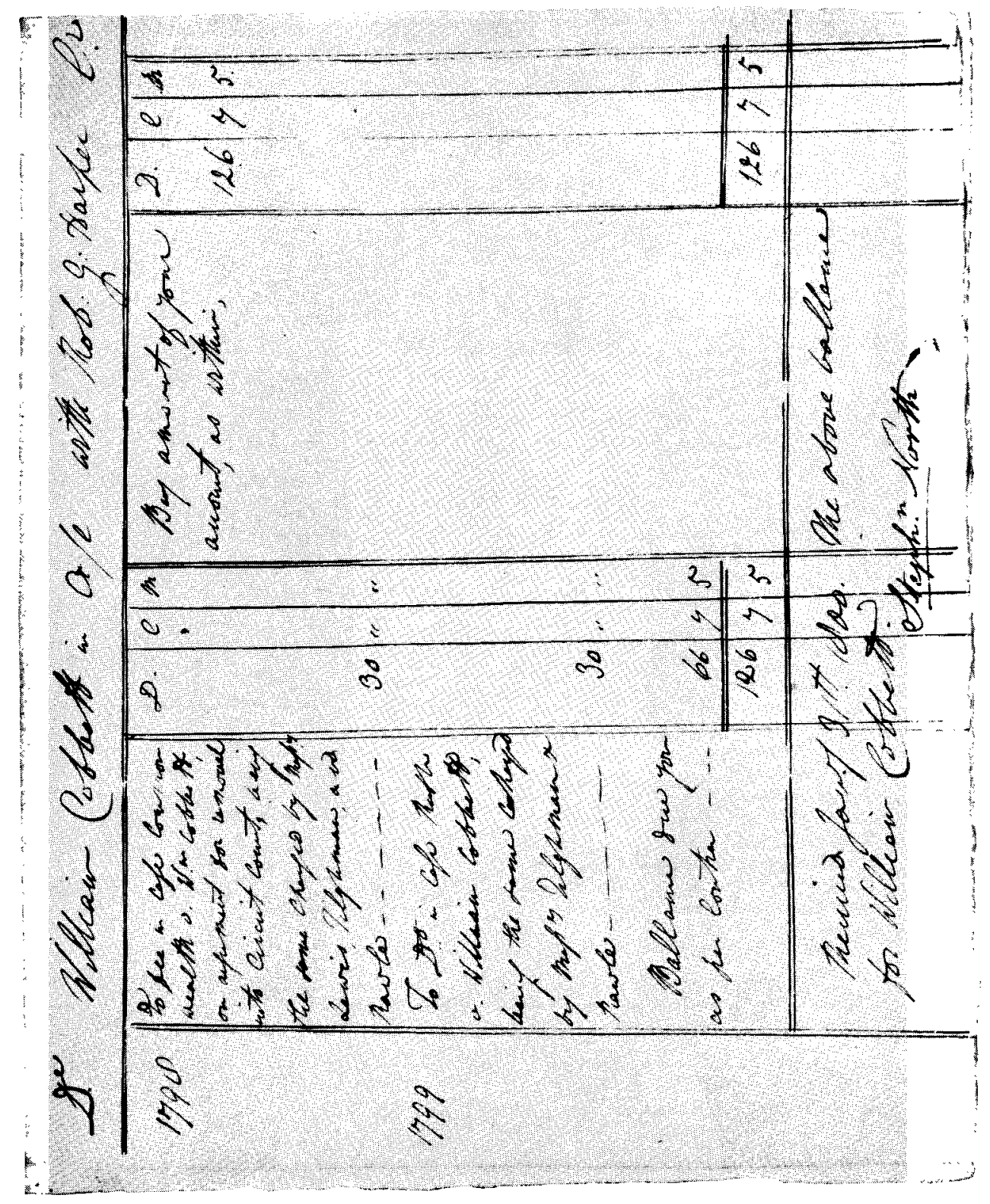


addition to works published in London, one published in Paris, one in Dublin, and one in Calcutta.

The sequel of this letter to Harper may be briefly told. Cobbett attempted to keep his head above water with attacks on Rush from the safety of New York. But he soon found that it was a difficult matter to establish himself in that city and even more difficult to make a continuing profit from the Rush-Light, which he published to deal with "the case of Rush against me." Some biographers believe that he was a failure in business in New York. He did indeed give up the struggle. He did sail for London and a new career on June I, I 800 . But one may well believe that he sailed not because of despair at prospects in New York but because a brighter future beckoned from the land he loved.

Below is transcribed Harper's bill:

1797

Nov ${ }^{\mathrm{r}} .6$

I 798

March 27

30

Ap 9

I 0

14

May 29

June 16

July I I

16

Augt. I

$\operatorname{Dec}^{\mathbf{r}}$. 19

$1799 \mathrm{Jan}^{\mathrm{y}} .24$
R. G. Harper To William Cobbett To Somerville's Political Transactions

275

35

650

- 100

$-50$

1 -

$-25$

325

3025

$-50$

$-25$

350

$-50$

$-50$

$-50$

$2-$

$-50$

I 75

3750

$-50$

5 -

250

$8-$

$8-$

I 25

3 - 


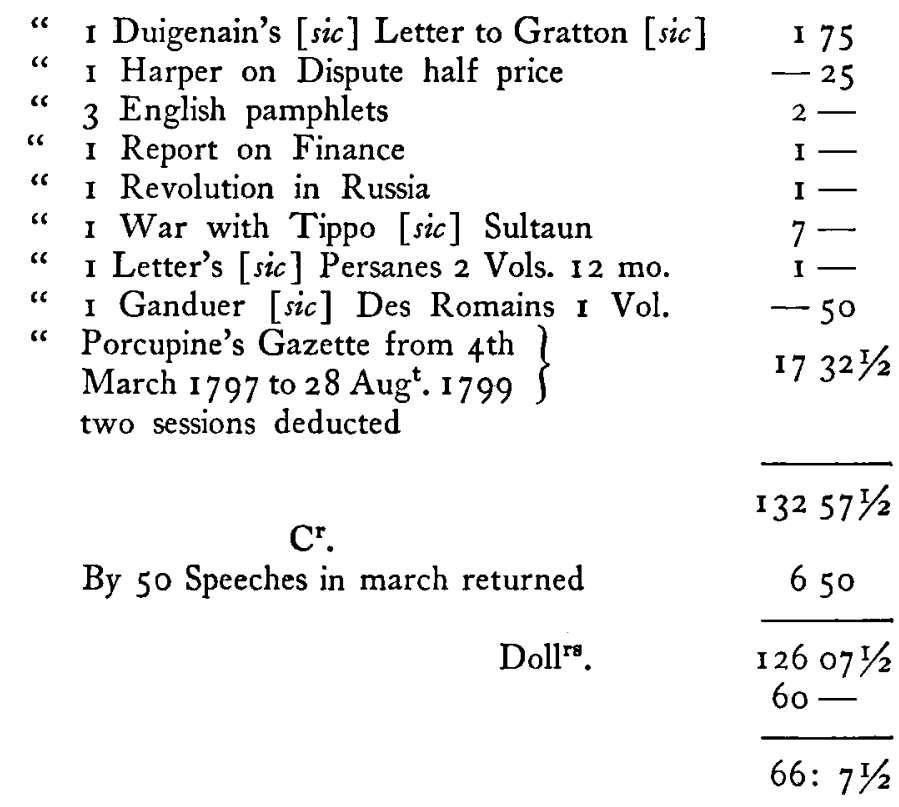

\section{Notes to the charges on Cobbett's bill to Harper}

Somerville's Political Transactions:

The History of Political Transactions, and of Parties, from the restoration of King Charles the Second, to the Death of King William. By Thomas Somerville, D.D. London, Printed for A. Strahan, and T. Cadell, 1792.

Speeches in May 1797:

Harper's Speech:

Speech of R. G. Harper. esqr., in the House of representatives, Monday, the 29th day of May, 1797, relative to the unjust, cruel, insolent and perfidious conduct of France towards the United States. Philadelphia: Published by William Cobbett, opposite Christ church. March, 1798.

so Do. March:

Mr. Harper's Speech on the foreign intercourse bill, in reply to Mr. Nicholas and Mr. Gallatin. Delivered in the committee of the whole of the House of Representatives of the United States, on Friday the second of March, 1798. [Philadelphia, 1798.]

Note: Whether this is the edition sold by Cobbett is uncertain; there was another edition during 1798 printed at Philadelphia by Richard Folwell.

Democratic Judge:

The Democratic Judge: or the equal liberty of the press, as exhibited, explained, and exposed in the prosecution of William Cobbett, for a pretended libel against the King of Spain and his embassador, before Thomas M'Kean, chief justice of the state of Pennsylvania. By Peter Porcupine. Philadelphia: Published by William Cobbett, opposite Christ-Church. March, I798.

Instructions to Envoys:

Not apparently a separate publication, this was printed as an appendix to Harper's Dispute, third edition (see below). It is likely that Harper, wanting a few copies of the appendix before the whole edition should be ready, obtained these from Cobbett as pre-prints. The full title of the appendix was: "Abstract of the Instructions to the En- 
voys Extraordinary of the United States, for Settling their Differences with the French Republic."

Dispute with France:

Observations on the Dispute Between the United States \& France, addressed by Robert Goodloe Harper, of South Carolina, to his Constituents, in May, I 797. Third American Edition. With a Preface \& Appendix \&c. Philadelphia: Published by William Cobbett, opposite Christ Church, May, 1798.

Note: William Reitzel, "Cobbett and Philadelphia Journalism," Pennsylvania Magazine of History and Biography, 59:24I) asserts that Cobbett published Harper's Dispute in June, 1797 , and that he advertised the same in Porcupine's Gazette for June 26, 1797. The latter statement only is correct. The first edition of Harper's Dispute-without preface or appendix but with the same title as above-had the following imprint: "Philadelphia: Printed and sold by Thomas Bradford, Book-seller \& Stationer, No. 8 South Front Street. I 797." Further, Evans's American Bibliography says of this edition: "I 87 th Pennsylvania Copyright issued to Thomas Bradford, as Proprietor, 24 June, I 797." It is Bradford's edition which Cobbett was advertising for sale in 1797 . In 1998 he arranged with Harper and Bradford the matter of copyright.

Cannibal's Progress:

The Cannibal's Progress: or the dreadful horrors of French Invasion, displayed by the republican officers and soldiers, in their perfidy, rapacity, ferociousness and brutality, exercised towards the innocent inhabitants of Germany. Translated from the German, by Anthony Aufrer, Esq. London: Published by Wright, Cadel and others; and republished at Philadelphia by William Cobbett. Price only 6 cents, I I for half a dollar, 25 for a dollar, 56 for 2 dollars, three dollars and a half per hundred. [1 798.$]$

Proofs of a Conspiracy:

Proofs of a conspiracy against all the Religions and Governments of Europe, carried on in the secret meetings of Free Masons, Illuminati, and Reading Societies. Collected from good authorities, by John Robison, A.M., Professor of Natural Philosophy, and Secretary to the Royal Society of Edinburgh. The Third Edition. To which is added a Postscript. Philadelphia: Printed for T. Dobson and W. Cobbet [sic]. I 798 .

Note: This was a reprint either of the first edition, Edinburgh and London 1797 , or of the second, Edinburgh 1798 .

Harper's Letter:

A Short Account of the Principal Proceedings of Congress, in the Late Session, and a Sketch of the State of Affairs between the United States and France in July, 1 798: in a Letter from Robert Goodloe Harper, of South Carolina, to one of his constituents. Philadelphia: Published by William Cobbett. August, 1798.

Bertrand's Memoirs:

Private Memoirs relative to the last year of the reign of Lewis the Sixteenth, late king of France. By Ant. Fr. Bertrand de Moleville ... Tr. from the original manuscript of the author, which has never been published. With five portraits ... of the royal family of France... London: A Strahan [etc], 1797 .

Gifford's French Revolution:

The Reign of Louis XVI. and complete history of the French Revolution; with notes critical and explanatory. By John Gifford. London, I 794 .

Pursuits of Literature:

The Pursuits of Literature. A satirical poem in four dialogs. With notes. Fourth Edition. London: T. Becket, n.d.

Note: It is impossible to be certain that this is the edition sold by Cobbett. Previous edd. contained fewer than the four dialogs of the complete work.

\section{Duigenain's Letter to Gratton:}

An answer to the Address of Henry Grattan ... to his fellow-citizens of Dublin, by Patrick Duigenan. Dublin: 1798. 
Note: This attack on Grattan "was rather a long satire, comprising 200 pages: it attacked the Catholics, contained great abuse of Ireland, and adulation of England." Henry Grattan (the younger), Memoirs of the Life and Times of the Rt. Hon. Henry Grattan, 5 vols. London, 1842. Vol. 4, P. 402.

Report on Finance:

An Account of the Receipts and Expenditures of the United States for the year 1798 ... Philadelphia ... I 799.

Note: The price and date of sale for "Report on Finance" suggest this identification.

Revolution in Russia :

A History, or anecdotes of the revolution in Russia, in the year 1762 . Translated from the French of M. de Rulhière. Boston: Printed by Manning \& Loring for J. Nancrede, No. 49 Marlbro' street. I 798.

Note: The first edition was published in French in Paris, 1797.

War with Tippo Sultaun:

A Sketch of the War with Tippoo Sultaun; or a detail of the military operations, from the commencement of Hostilities ... in December, 1789 , until the peace concluded . . . in February, 1792. By Lieutenant Mackenzie. 2 vols. Calcutta: 1793-1 794.

Note: Tippoo Sahib, Sultan of Mysore ( $1753-1799$ ) was finally defeated by troops led by Lord Cornwallis, in 1792.

\section{Letter's Persanes:}

Lettres Persanes, par M. de Montesquieu, nouvelle édition augmentée de douze lettres qui ne se trouvent point dans les précédentes et suivie du "Temple de Guide." 2 vols. Londres, 1784 .

Ganduer Des Romains:

Considérations sur les causes de la grandeur des Romains et de leur décadence, par Montesquieu. [avec l'éloge de Montesquieu par d'Alembert et le Dialogue de Sylla et d'Eucrate .... Paris: I795.

Porcupine's Gazette:

Published by William Cobbett as a daily evening paper, Sundays and certain holidays omitted, from March 4, 1797, to August 28, 1799.

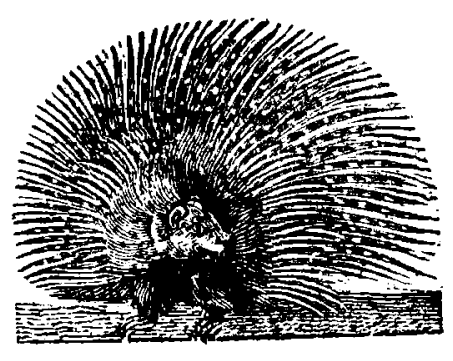

FROM MASTHEAD OF

Porcupine's Gazette 